\title{
Supercritical carbon dioxide extract of Physalis peruviana induced cell cycle arrest and apoptosis in human lung cancer H661 cells
}

\author{
Shu-Jing $\mathrm{Wu}^{\mathrm{a}}$, Shun-Pang Chang ${ }^{\mathrm{b}}$, Doung-Liang Lin ${ }^{\mathrm{c}}$, Shyh-Shyan Wang ${ }^{\mathrm{c}}$, Fwu-Feuu Hou ${ }^{\mathrm{c}}$, Lean-Teik $\mathrm{Ng}^{\mathrm{d}, *}$ \\ ${ }^{a}$ Graduate Institute of Nutritional Health, Chia-Nan University of Pharmacy and Science, Tainan, Taiwan \\ ${ }^{\mathrm{b}}$ Department of Biotechnology, Chia-Nan University of Pharmacy and Science, Tainan, Taiwan \\ ${ }^{\mathrm{c}}$ Tainan District Agricultural Research and Extension Station, Tainan, Taiwan \\ ${ }^{\mathrm{d}}$ Department of Agricultural Chemistry, National Taiwan University, No. 1, Sec. 4, Roosevelt Road, Taipei 106, Taiwan
}

\section{A R T I C L E I N F O}

\section{Article history}

Received 3 October 2008

Accepted 27 January 2009

\section{Keywords:}

Physalis peruviana

Supercritical carbon dioxide extraction

Cell cycle arrest

Apoptosis

\begin{abstract}
A B S T R A C T
Physalis peruviana L. (PP) is a popular folk medicine used for treating cancer, leukemia, hepatitis, rheumatism and other diseases. In this study, our objectives were to examine the total flavonoid and phenol content of different PP extracts (aqueous: HWEPP; ethanolic: EEPP; supercritical carbon dioxide: SCEPP-0, SCEPP-4 and SCEPP-5) and their antiproliferative effects in human lung cancer H661 cells. Among all the extracts tested, results showed that SCEPP-5 possessed the highest total flavonoid $(226.19 \pm 4.15 \mathrm{mg} / \mathrm{g})$ and phenol $(100.82 \pm 6.25 \mathrm{mg} / \mathrm{g})$ contents. SCEPP-5 also demonstrated the most potent inhibitory effect on H661 cell proliferation. Using DNA ladder and flow cytometry analysis, SCEPP-5 effectively induced H661 cell apoptosis as demonstrated by the accumulation of Sub-G1 peak and fragmentation of DNA. SCEPP-5 not only induced cell cycle arrest at S phase, it also up-regulated the expression of pro-apoptotic protein (Bax) and down-regulated the inhibitor of apoptosis protein (IAP). Furthermore, the apoptotic induction in H661 cells was found to associate with an elevated p53 protein expression, cytochrome $c$ release, caspase-3 activation and PARP cleavage. Taken together, these results conclude that SCEPP-5 induced cell cycle arrest at $S$ phase, and its apoptotic induction could be mediated through the p53-dependent pathway and modification of Bax and XIAP proteins expression. The results have also provided important pharmacological backgrounds for the potential use of PP supercritical fluid extract as products for cancer prevention.
\end{abstract}

(c) 2009 Published by Elsevier Ltd.

\section{Inroduction}

Physalis peruviana L. of family Solanaceae has been widely used in folk medicine for treating cancer, leukemia, hepatitis, rheumatism and other diseases (Perry, 1980; Wu et al., 2004a). Its major bioactive compounds, physalins ( $\mathrm{A}, \mathrm{B}, \mathrm{D}$ and $\mathrm{F}$ ) and glycosides (such as myricetin-3-O-neohesperidoside) were shown to exert activities on HA 22T (hepatoma), HeLa (cervix uteri), leukemia, and KB-16 (nasopharynx) cancer cell lines (Chiang et al., 1992a,b; Ismail et al., 2001). Studies have demonstrated that ethanol extract of PP possessed potent antioxidant (Wu et al., 2005) and antihepatoma (Hep G2) (Wu et al., 2004a,b) activities. SFE- $\mathrm{CO}_{2}$ extract of PP was shown to possess antioxidant and anti-inflammatory activities (Wu et al., 2006). In supercritical fluid extraction (SFE), carbon dioxide $\left(\mathrm{CO}_{2}\right)$ has the advantage of being chemically inert, and hence is a preferable solvent for use in natural product, food, flavor and pharmaceutical extraction (Yang et al., 2002; Leal et al., 2003; Wang et al., 2005).

\footnotetext{
* Corresponding author. Tel.: +886 2 33664804; fax: +886 233669907 .

E-mail address: nglt97@ntu.edu.tw (L.-T. Ng).
}

Recently, there has been an increasing interest in the anticancer properties of plant-based drugs and intensive studies have been conducted to examine their apoptotic effects. It is now known that apoptosis or programmed cell death is the central to the process of animal development and tissue homeostasis (Meier et al., 2000). Failure to regulate apoptosis is linked to a number of human pathologies such as cancer, autoimmune diseases and neurodegenerative disorders (Thompson, 1995; Kroemer and Reed, 2000).

In response to DNA damage by anticancer agents, p53 directly activated the promoter of the CD95 (APO-1) gene. The up-regulation of the CD95 death receptor has been observed in cells with wild-type p53 but not in cells with mutant or null p53 (Muller et al., 1998). p53 activation could alter the transcription of a wide variety of genes involving in cell metabolism, cell cycle regulation and apoptosis (Lee et al., 2003). Both pro-apoptotic (Bax, Bak, Bid, Noxa etc) and anti-apoptotic (Bcl-2, Bcl-xL, Mcl-1, Bcl-w etc) proteins are known to be key regulators of apoptosis (Adams and Cory, 1998). Genes transcriptionally up-regulated by p53 that have been implicated in promoting apoptosis include the Bcl-2 family members, namely Bax, Bak and Noxa gene proteins (Borner, 2003; Lee 
et al., 2003). The activation of caspase-3 is required for p53-dependent apoptotic pathway, which leads to the cellular protein cleavage (e.g. PARP), DNA damage and cell death.

In the mitochondrial pathway, several death-promoting factors have been identified, including cytochrome $c$, AIF, Smac (also known as DIABLO), and endonuclease G (McNeish et al., 2003; Yamaguchi et al., 2003). AIF and endonuclease $G$ are able to directly cause nuclear and DNA damage, whereas cytochrome $c$ works together with apoptosis protease-activating factor-1 (Apaf1 ) to activate caspase 9 , followed by activating caspase- 3 , and consequently resulting in cell apoptosis (Cain et al., 2002). For the Xlinked inhibitor of apoptosis protein (XIAP), cIAP-1 and -2, and survivin are prominent members of the inhibitor of apoptosis protein (IAP) family that can exert anti-apoptotic effects by interfering with the processing and activities of the executioner caspase-3, -7 and -9 (Roy et al., 1997; Woo et al., 2003).

In this study, our aims were: (i) to identify a more effective extraction method for preparing PP extract; (ii) to evaluate the anticancer activity of various PP extracts, including aqueous, ethanolic and SFE extracts in human lung cancer H661 cells and (iii) to investigate the cell death signaling effects of bioactive PP extract (i.e. SCEPP-5) on the expression of CD95 (APO-1/CD95), CD95L, p53, p-p53, Bcl-2 family proteins (Bax and $\mathrm{Bcl}-2$ ) and XIAP, as well as cytochrome $c$ release, caspase- 3 activation, and PARP cleavage.

\section{Materials and methods}

\subsection{Reagents}

RPMI-1640 medium, dimethyl sulfoxide (DMSO), 3-(4,5-dimethylthiazol-2-yl)2,5-diphenyl-tertazolium bromide (MTT), penicillin, streptomycin, tryspin-EDTA and anti- $\beta$-actin were purchased from Sigma Chemical Co. (St. Louis, MO, USA). Fetal bovine serum (FBS) was obtained from GIBCO BRL (Gaithersburg, MD, USA). The anti-Bax, anti-Bcl-2, anti-caspase-3, anti-XIAP, anti-CD95 (APO-1/CD95), antiCD95L, anti-cytochrome $c$ and anti-PARP antibodies were purchased from PharMingen (San Diego, CA, USA). The anti-p53 and anti-p-p53 were obtained from Cell Signaling Technology, Inc. (Beverly, MA, USA). Anti-mouse IgG antibody was from Promega (Madison, WI, USA).

\subsection{Plant materials}

The plant material of P. peruviana (PP) was obtained from Tainan District Agriculture Improvement Station, Taiwan. Its authenticity was confirmed by Prof. C.C. Lin (Kaohsiung Medical University, Taiwan). The PP leaves were dried and ground to powdered-form, which was then kept in an air-tight brown bottle until use.

\subsection{Extract preparation}

To prepare the aqueous extract, $100 \mathrm{~g}$ of PP powder was extracted with 1 liter of boiling water for $1 \mathrm{~h}$. The extract was filtered with filter paper (Advantec No. 1, Japan) while the residue was re-extracted under the same conditions twice. The filtrates obtained from the three separate extractions were combined, concentrated and then lyophilized.

To prepare the ethanolic extract, $100 \mathrm{~g}$ of PP powder was soaked with 1 liter of ethanol (95\%) at room temperature for 6 days. After filtering the extract with filter paper (Advantec No. 1, Japan), the filtrate collected was concentrated and lyophilized.

The dried aqueous (HWEPP) and ethanolic (EEPP) extracts were collected, weighed and stored at $4{ }^{\circ} \mathrm{C}$ until use.

\subsection{Preparation of P. peruviana extract using supercritical fluid extraction (SFE)}

The extraction was performed according to procedures described by Yang et al. (2002). In brief, $5 \mathrm{~g}$ of PP powder was taken and placed in the SFE cartridge. The PP extract was mixed without or with $4 \%$, or $5 \%$ ethanol as modifier, and then continuously fed counter currently into a supercritical fluid system (Applied Separations, Allentown, PA, USA) together with liquid $\mathrm{CO}_{2}$. The SFE process consisted of a static extraction time of $5 \mathrm{~min}$ followed by a dynamic extraction for $30 \mathrm{~min}$ to $1 \mathrm{~h}$. The restrictor temperature and extraction pressure were set at $60^{\circ} \mathrm{C}$ and $400 \mathrm{bar}$, respectively. Extracts were collected in $10 \mathrm{ml}$ ethanol. After removing the solvent the dried SFE- $\mathrm{CO}_{2}$ PP extract was collected, weighed and subjected to subsequent chemical and biological analyses. Sample SCEPP- 0 was obtained without ethanol as modifier, while SCEPP-4 and SCEPP-5 was obtained with $4 \%$ and $5 \%$ ethanol as modifier, respectively.

\subsection{Total flavonoid analysis}

The total flavonoid content of PP extracts was determined by the colorimetric method. In brief, $0.5 \mathrm{ml}$ of sample solution was mixed with $2 \mathrm{ml}$ of distilled water and subsequently with $0.15 \mathrm{ml}$ of $5 \% \mathrm{NaNO}_{2}$ solution. After 6 min of incubation, $0.15 \mathrm{ml}$ of $10 \% \mathrm{AlCl}_{3}$ solution was added and allowed to stand for $6 \mathrm{~min}$, followed by adding $2 \mathrm{ml}$ of $4 \% \mathrm{NaOH}$ solution to the mixture. Immediately after water was added to the sample to bring to the final volume of $5 \mathrm{ml}$, the mixture was thoroughly mixed and allowed to stand for another $15 \mathrm{~min}$. The mixture absorbance was determined at wavelength $510 \mathrm{~nm}$. All values were expressed in milligrams of rutin equivalents per gram of extract.

\subsection{Total phenol analysis}

The total phenol content of PP extracts was analyzed by the Folin-Ciocalteu method. In brief, after PP extracts were well mixed with $2.5 \mathrm{ml}$ of distilled water and $0.5 \mathrm{ml}$ of the Folin-Ciocalteu stock reagent, $1.0 \mathrm{ml}$ of $\mathrm{Na}_{2} \mathrm{CO}_{3}$ reagent $(75 \mathrm{~g} / \mathrm{l})$ was added to the mixture and then incubated at room temperature for $30 \mathrm{~min}$. The mixture absorbance was measured at wavelength $765 \mathrm{~nm}$. The total phenol content was expressed in milligrams of gallic acid equivalents per gram of extract.

\subsection{Cell culture and drug preparation}

The H661 cell line (ATCC HTB 183) was obtained from the American Type Culture Collection (Rockville, MD, USA). Cells were grown in 90\% RPMI-1640 medium supplemented with $10 \%$ FBS, 100 units $/ \mathrm{ml}$ penicillin and $100 \mu \mathrm{g} / \mathrm{ml}$ streptomycin. They were maintained at $37{ }^{\circ} \mathrm{C}$ in a humidified atmosphere of $5 \% \mathrm{CO}_{2}$.

Extracts of PP stock solution were prepared in DMSO at concentration $1 \mathrm{mg} / \mathrm{ml}$ and was stored at $-20^{\circ} \mathrm{C}$ until use. The concentrations used for the study were 1 , $10,30,50$ and $100 \mu \mathrm{g} / \mathrm{ml}$, which were freshly prepared for each experiment with a final DMSO concentration of $0.1 \%$. Control was always treated with the same amount of DMSO $(0.1 \% ; \mathrm{v} / \mathrm{v})$ as used in the corresponding experiments.

\subsection{Anticancer activity assay}

The percentage of apoptotic cells was colorimetrically measured using MTT according to the manufacturer's instructions. Cells were cultured at $1 \times 10^{5}$ cells per well in 96-well plates containing $100 \mu \mathrm{l}$ of RPMI-1640 medium. After an overnight incubation, cells were treated with 0.1\% DMSO (as control), HWEPP, EEPP, SCEPP-0, SCEPP- 4 and SCEPP-5 for $24 \mathrm{~h}$. They were then washed once before adding $50 \mu \mathrm{l}$ of FBS-free medium containing MTT $(5 \mathrm{mg} / \mathrm{ml})$. After $4 \mathrm{~h}$ of incubation at $37^{\circ} \mathrm{C}$, the medium was discarded and the formazan blue that formed in the cells was dissolved in DMSO. The optical density was measured at $550 \mathrm{~nm}$.

\subsection{Cell cycle analysis}

After $24 \mathrm{~h}$ of incubation, cells were treated with $0.1 \%$ DMSO (control), 1,10 and $50 \mu \mathrm{g} / \mathrm{ml}$ SCEPP-5. Floating and adherent cells were then collected. The cells in suspension were fixed with $70 \%$ ice-cold methanol and then transferred to the freezer until use. After washing with PBS, cells were stained with $50 \mu \mathrm{g} / \mathrm{ml}$ propidium iodide (PI) in the presence of $25 \mu \mathrm{g} / \mathrm{ml}$ RNase A at $37^{\circ} \mathrm{C}$ for $30 \mathrm{~min}$. A minimum of 10,000 cells per sample was collected for estimating the percentage of each phase in cell cycle. The DNA histograms were analyzed by Multicycle software (Phoenix Flow Systems, San Diego, CA, USA).

\subsection{DNA fragmentation assay}

Cells were grown to about $80 \%$ confluence and then treated with $0.1 \%$ DMSO (control) and $50 \mu \mathrm{g} / \mathrm{ml} \mathrm{SCEPP-5}$ for $24 \mathrm{~h}$. After treatment, they were washed with PBS, and pelleted by centrifugation at $200 \mathrm{~g}$ at $4{ }^{\circ} \mathrm{C}$. The pellet was suspended in $195 \mu \mathrm{l}$ of DNA lysis buffer [740 $\mu$ lysis buffer containing $37 \mu \mathrm{l}$ of $1 \mathrm{M}$ Tris $(\mathrm{pH}$ 8.0 ), $14.8 \mu \mathrm{l}$ of $0.5 \mathrm{M}$ EDTA, $10 \mu \mathrm{l}$ of $75 \%$ sodium lauryl sarcosine and $678.2 \mu \mathrm{l}$ of $\mathrm{H}_{2} \mathrm{O}$ land digested overnight with proteinase $\mathrm{K}(0.5 \mathrm{mg} / \mathrm{ml})$ at $50{ }^{\circ} \mathrm{C}$, followed by adding $10 \mu \mathrm{l}$ of Rnase $(\mu \mathrm{g} / \mathrm{ml})$ and left reacted at $50^{\circ} \mathrm{C}$ for $1 \mathrm{~h}$. DNA was extracted using phenol:chloroform $(1: 1 ; \mathrm{v} / \mathrm{v})$ and then loaded onto a $2.0 \%$ agarose gel for electrophoresis. After staining with ethidium bromide, samples were visualized under UV light.

\subsection{Western immunoblot analysis}

Cells were harvested and lysed in ice-cold buffer (10 mM Tris- $\mathrm{HCl}, \mathrm{pH} 7.5,0.1 \%$ $\mathrm{NP}-40,0.5 \%$ sodium deoxycholate, $0.1 \%$ SDS, $1 \mathrm{mM}$ sodium orthovanate and $120 \mathrm{mM}$ sodium chloride) containing $1 \mathrm{mM}$ phenylmethylsulfonyl fluoride, $10 \mu \mathrm{g}$ / $\mathrm{ml}$ leupeptin and $1 \mu \mathrm{g} / \mathrm{ml}$ aprotonin (Sigma Chemical Co., St. Louis, MO, USA). Lysates were centrifuged at $10,000 \mathrm{~g}$ for $10 \mathrm{~min}$. Equal amounts of lysate protein ( $50 \mu \mathrm{g} / \mathrm{lane})$ were then loaded onto SDS-polyacrylamide gels and electrophoretically transferred to a PVDF membrane (Bio-Rad Laboratories, Hercules, CA, USA). After inhibiting the nonspecific binding sites with $5 \%(\mathrm{w} / \mathrm{v})$ skim milk in $0.1 \%$ $(\mathrm{v} / \mathrm{v})$ Tween 20 containing PBS (PBST) for $1 \mathrm{~h}$ at room temperature, the membrane 
was incubated with the specific primary antibodies [i.e. anti-Bax (1:250), anti-Bcl-2 (1:1000), anti-caspase-3 (1:1000), anti-CD95 (APO-1/CD95) (1:5000), anti-CD95L (1:5000), anti-XIAP (1:250), anti-p53 (1:500), anti-p-p53 (1:1000)], and anti-ß-actin (1:5000) antibodies in 5\% $(\mathrm{w} / \mathrm{v})$ skim milk in PBST for $1 \mathrm{~h}$ at room temperature. Antibody recognition was detected with the respective secondary antibody, either anti-mouse IgG or anti-rabbit IgG antibodies linked to horseradish peroxidase. Antibody-bound proteins were detected by the ECL western blotting analysis system (Amersham Corp., Aylesbury, UK). The expression of ß-actin was used as a control.

\subsection{Statistical analysis}

Data were presented as means \pm standard deviations (SD). Values were evaluated by one way ANOVA, followed by Duncan's multiple range tests. $P$-value $<0.05$ was considered as significantly difference.

\section{Results}

\subsection{Yield of P. peruviana extract obtained by different extraction methods}

The yield of PP extracts obtained by hot water (HWEPP) and ethanol (EEPP) was $20.99 \%$ and $28.32 \%$, respectively (Table 1 ). A considerable variation in yield was noted in different conditions of SFE. The yield of SFE- $\mathrm{CO}_{2}$ extracts was found to increase with increasing percentage of modifier, that was from $8.22 \%$ for $4 \%$ ethanol (SCEPP-4) to $17.61 \%$ for $5 \%$ ethanol (SCEPP-5). The yield for $0 \%$ (SCEPP-0) modifier was 3.37\%.

\subsection{Total flavonoid and phenol contents of P. peruviana extracts}

Results showed that EEPP possessed a higher total flavonoid and phenol contents than HWEPP and SCEPP-0 extracts, but was lower than SCEPP-4 and SCEPP-5. With increasing concentration of ethanol as modifier in SFE- $\mathrm{CO}_{2}$, an increase in total flavonoid and phenol contents was noted. Among the different extracts, SCEPP-5 displayed the highest content in total flavonoids $(226.19 \pm 4.15 \mathrm{mg} / \mathrm{g})$ and phenols $(100.82 \pm 6.25 \mathrm{mg} / \mathrm{g}$ ) (Table 2$)$.

\subsection{SCEPP-5 inhibited proliferation of H661 cells}

To examine the antiproliferative effects of different PP extracts, cells were subjected to $24 \mathrm{~h}$ treatment with $0.1 \%$ DMSO (control), HWEPP, EEPP, SCEPP-0, SCEPP-4 and SCEPP-5, followed by evaluating the percentage of apoptotic cells with MTT assay. Results showed that SCEPP-5 displayed a lower $\mathrm{IC}_{50}$ value $(51.44 \pm 1.55 \mu \mathrm{g} / \mathrm{ml}$ ) than other treatments (Table 3), suggesting that SCEPP-5 possessed the strongest antiproliferative effect on H661 cells. It is therefore, selected for detailed antiproliferative studies.

To determine the time-concentration effects of SCEPP-5 on H661 cells, cells were treated with $0,1,10,30,50$ and $100 \mu \mathrm{g} / \mathrm{ml}$ SCEPP-5 for 6, 12 and $24 \mathrm{~h}$. Results showed that SCEPP-5 effectively suppressed the proliferation of H661 cells in a dose- and timedependent manner (Table 4). After treating with SCEPP-5 at con-

Table 1

Effects of extraction method on the yield of $P$. peruviana extracts.

\begin{tabular}{lc}
\hline Treatment & Yield $(\mathrm{g} / 100 \mathrm{~g}$ dry mass $)$ \\
\hline HWEPP & $20.99 \pm 1.11^{\mathrm{b}}$ \\
EEPP & $28.32 \pm 0.95^{\mathrm{a}}$ \\
SCEPP-0 & $3.37 \pm 0.41^{\mathrm{e}}$ \\
SCEPP-4 & $8.22 \pm 0.91^{\mathrm{d}}$ \\
SCEPP-5 & $17.61 \pm 0.27^{\mathrm{c}}$ \\
\hline
\end{tabular}

Each data represents the mean \pm SD of three independent experiments. Means with the different superscript letters were significantly different at $P<0.05$ as analyed by Duncan's multiple range tests.
Table 2

Total flavonoid and phenol contents of different P. peruviana extracts.

\begin{tabular}{lcr}
\hline Samples & Flavonoids $(\mathrm{mg} / \mathrm{g})$ & Phenols $(\mathrm{mg} / \mathrm{g})$ \\
\hline HWEPP & $37.39 \pm 3.45^{\mathrm{e}}$ & $18.57 \pm 0.91^{\mathrm{d}}$ \\
EEPP & $94.97 \pm 3.18^{\mathrm{c}}$ & $85.81 \pm 3.09^{\mathrm{b}}$ \\
SCEPP-0 & $57.36 \pm 2.46^{\mathrm{d}}$ & $9.50 \pm 0.32^{\mathrm{e}}$ \\
SCEPP-4 & $212.51 \pm 7.43^{\mathrm{b}}$ & $70.53 \pm 1.25^{\mathrm{c}}$ \\
SCEPP-5 & $226.19 \pm 4.15^{\mathrm{a}}$ & $100.82 \pm 6.25^{\mathrm{a}}$
\end{tabular}

Each data represents the mean \pm SD of three independent experiments. Means within the same column with the different superscript letters were significantly different at $P<0.05$ as analyzed by Duncan's multiple range tests.

Table 3

$\mathrm{IC}_{50}$ values of cytotoxicty of different $P$. peruviana extracts.

\begin{tabular}{ll}
\hline Samples & $\mathrm{IC}_{50}(\mu \mathrm{g} / \mathrm{ml})$ \\
\hline HWEPP & $>100.00$ \\
EEPP & $57.38 \pm 1.00$ \\
SCEPP-0 & $>100.00$ \\
SCEPP-4 & $80.78 \pm 3.20$ \\
SCEPP-5 & $51.44 \pm 1.55$
\end{tabular}

Each value represents the mean \pm SD of three independent experiments. Anticance activity was determined by MTT assay. $\mathrm{IC}_{50}$ (50\% inhibitory concentration) was the concentration of $P$. peruviana extracts required for the $50 \%$ inhibition of $\mathrm{H} 661$ cell proliferation.

Table 4

Antiproliferative effect of SCEPP-5 on H661 cells.

\begin{tabular}{lcrr}
\hline Treatment $(\mu \mathrm{g} / \mathrm{ml})$ & \multicolumn{3}{l}{ \% Inhibition } \\
\cline { 2 - 4 } & $6 \mathrm{~h}$ & \multicolumn{1}{l}{$12 \mathrm{~h}$} & \multicolumn{1}{c}{$\mathrm{h}$} \\
\hline Control & $0.00 \pm 2.15^{\mathrm{c}}$ & $0.00 \pm 0.88^{\mathrm{c}}$ & $0.00 \pm 1.52^{\mathrm{e}}$ \\
1 & $5.50 \pm 0.90^{\mathrm{b}}$ & $1.90 \pm 0.40^{\mathrm{c}}$ & $1.12 \pm 0.73^{\mathrm{e}}$ \\
10 & $4.21 \pm 1.42^{\mathrm{b}}$ & $6.27 \pm 0.22^{\mathrm{b}}$ & $9.84 \pm 1.34^{\mathrm{d}}$ \\
30 & $5.21 \pm 0.03^{\mathrm{b}}$ & $7.04 \pm 0.50^{\mathrm{b}}$ & $26.28 \pm 0.84^{\mathrm{c}}$ \\
50 & $5.00 \pm 1.72^{\mathrm{b}}$ & $7.62 \pm 1.04^{\mathrm{b}}$ & $49.41 \pm 0.35^{\mathrm{b}}$ \\
100 & $14.16 \pm 1.02^{\mathrm{a}}$ & $32.49 \pm 2.96^{\mathrm{a}}$ & $75.72 \pm 0.80^{\mathrm{a}}$ \\
\hline
\end{tabular}

Values are means \pm SD of three independent experiments. Means within the same column with the different superscript letters were significantly different at $P<0.05$ as analyzed by Duncan's multiple range tests.

centrations of 50 and $100 \mu \mathrm{g} / \mathrm{ml}$ for $24 \mathrm{~h}$, a high correlation between drug concentration and inhibition of cell growth was noted.

\subsection{Induction of apoptosis by SCEPP-5}

To further confirm that SCEPP-5 leads to apoptosis, cells were treated with various concentrations of SCEPP-5 $(0-50 \mu \mathrm{g} / \mathrm{ml})$ for $24 \mathrm{~h}$ and then analyzed by flow cytometry. As shown in Table 5, SCEPP-5 treatment resulted in an increment of the sub-G1 peak in a dose-dependent manner. A significant increase in the number of apoptotic cells was noted with increasing concentrations of
Table 5

Effect of different concentrations of SCEPP-5 on cell cycle progression.

\begin{tabular}{lllr}
\hline Treatment $(\mu \mathrm{g} / \mathrm{ml})$ & $\%$ & \\
\cline { 2 - 4 } & $\mathrm{G} 0 / \mathrm{G} 1$ & $\mathrm{~S}$ & \multicolumn{1}{c}{$\mathrm{G} 2 / \mathrm{M}$} \\
\hline Control & $62.58 \pm 3.18^{\mathrm{a}}$ & $30.27 \pm 8.36^{\mathrm{b}}$ & $7.15 \pm 5.56^{\mathrm{a}}$ \\
1 & $53.97 \pm 3.82^{\mathrm{ab}}$ & $35.79 \pm 3.54^{\mathrm{ab}}$ & $10.24 \pm 5.50^{\mathrm{a}}$ \\
10 & $49.22 \pm 7.74^{\mathrm{bc}}$ & $42.83 \pm 11.37^{\mathrm{ab}}$ & $7.95 \pm 3.81^{\mathrm{a}}$ \\
50 & $40.27 \pm 3.95^{\mathrm{c}}$ & $46.14 \pm 6.20^{\mathrm{a}}$ & $13.59 \pm 3.38^{\mathrm{a}}$ \\
\hline
\end{tabular}

Values are means $\pm S D$ of three independent experiments. Means within the same column with the different superscript letters were significantly different at $P<0.05$ as analyzed by Duncan's multiple range tests. 
SCEPP-5 treatment. At $50 \mu \mathrm{g} / \mathrm{ml}$, SCEPP- 5 treatment resulted in the formation of DNA fragments in H661 cells (Fig. 1).

\subsection{SCEPP-5 induced cell cycle arrest}

After $24 \mathrm{~h}$ of treatment, results showed that SCEPP-5 induced cell cycle arrest at $S$ phase and decreased in the G0/G1 phase of H661 cells in a dose-dependent manner (Table 5). In addition, treatment with SCEPP-5 at $0-50 \mu \mathrm{g} / \mathrm{ml}$ also displayed a dosedependent increased accumulation (from 5.87\% to 49.12\%) of the Sub-G1 peak (hypoploid) (Table 6).

\subsection{Apoptotic signaling pathway in SCEPP-5 treated H661 cells}

This study was conducted to investigate whether death receptors of CD95 (APO-1/CD95) and CD95L were involved in the SCEPP-5-induced apoptosis. Results showed that a dose- and time-dependent decrease in the expression of CD95 (APO-1/ CD95) protein levels in SCEPP-5 treated cells (Fig. 2A and B). CD95L expression was also appeared to involve in the SCEPP-5 induced H661 cell apoptosis (Fig. 2A).

\subsection{Regulation of p53, $p$-p53, Bcl-2 family proteins and cytochrome $c$ expression in $\mathrm{H} 661$ cells}

As shown in Fig. 3A and B, treatment with $50 \mu \mathrm{g} / \mathrm{ml}$ of SCEPP-5 resulted in the down-regulation of the anti-apoptotic (Bcl-2) and p-p53 proteins, and the up-regulation of the pro-apoptotic (Bax)

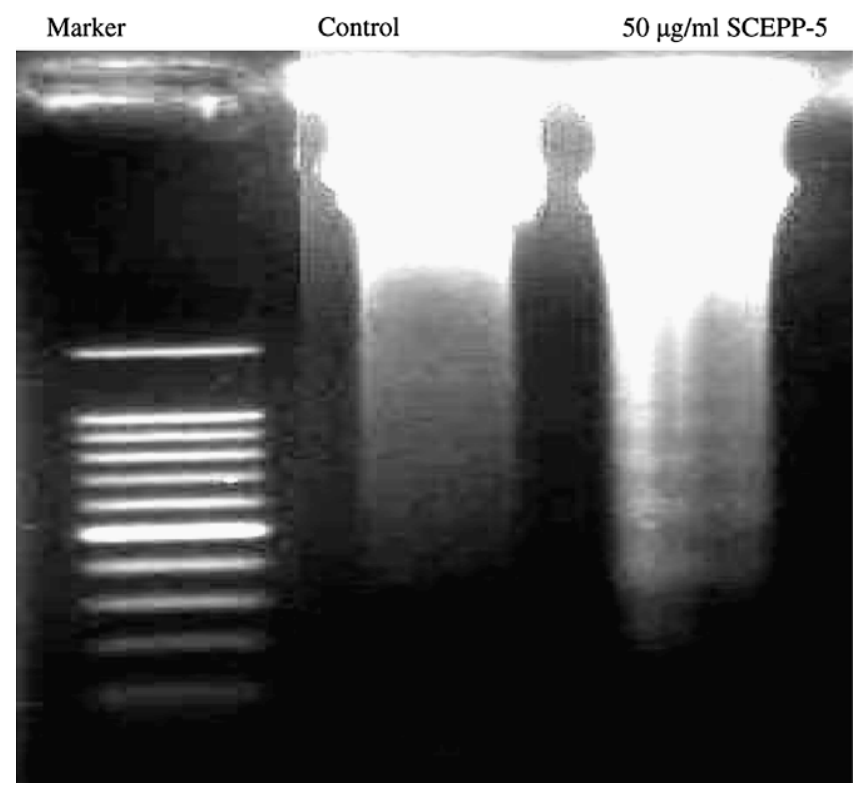

Fig. 1. SCEPP-5 induced H661 cell apoptosis. Cells were treated with vehicle and $50 \mu \mathrm{g} / \mathrm{ml} \mathrm{SCEPP}-5$ for $24 \mathrm{~h}$, and then DNA fragmentation was assessed by agarose gel electrophoresis.

Table 6

Effect of different concentrations of SCEPP-5 on Sub-G1 distribution.

\begin{tabular}{lr}
\hline Treatment $(\mu \mathrm{g} / \mathrm{ml})$ & \multicolumn{1}{c}{ Sub-G1 $(\%)$} \\
\hline Control & $5.87 \pm 1.27^{\mathrm{c}}$ \\
1 & $5.84 \pm 1.49^{\mathrm{c}}$ \\
10 & $16.10 \pm 1.14^{\mathrm{b}}$ \\
50 & $49.12 \pm 0.85^{\mathrm{a}}$ \\
\hline
\end{tabular}

Values are means $\pm S D$ of three independent experiments. Means within the same column with the different superscript letters were significantly different at $P<0.05$ as analyzed by Duncan's multiple range tests.

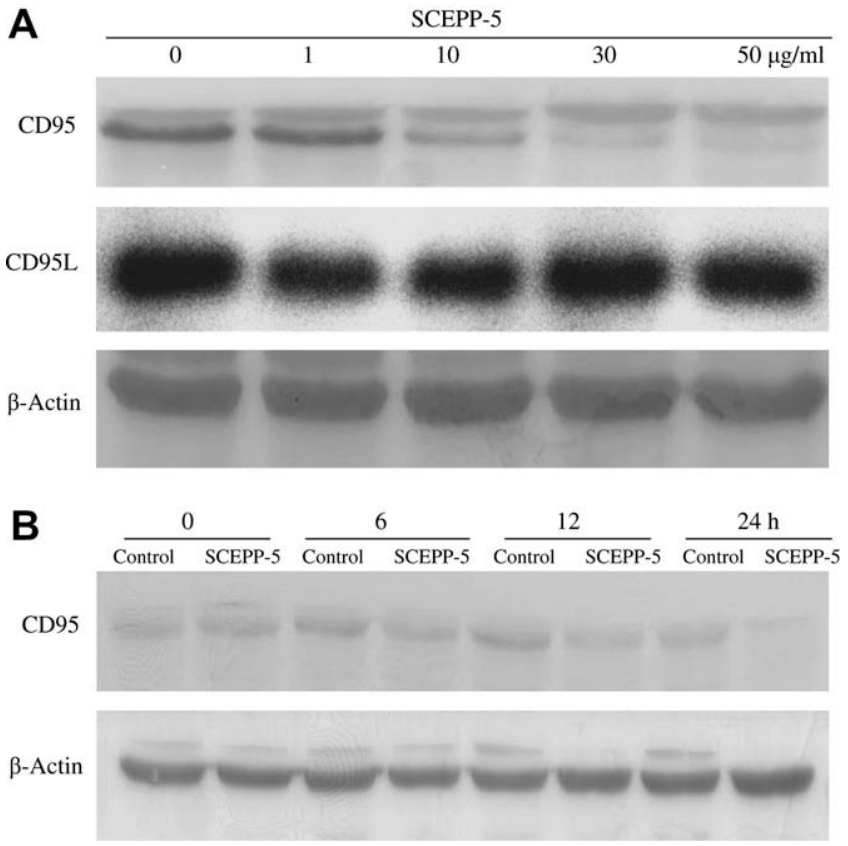

Fig. 2. Effects of SCEPP-5 on expression of CD95 and CD95L. (A) Cells were treated with $0,1,10,30$ and $50 \mu \mathrm{g} / \mathrm{ml} \mathrm{SCEPP-5}$ for $24 \mathrm{~h}$ and (B) cells were treated $0.1 \%$ DMSO (control) and $50 \mu \mathrm{g} / \mathrm{ml}$ SCEPP-5 for $0,6,12$ and $24 \mathrm{~h}$. $\beta$-Actin was used as a positive control.

protein in a dose- and time-dependent fashion. The expression of Bcl-2 protein was gradually disappeared after $24 \mathrm{~h}$ of SCEPP-5 treatment. As expected, SCEPP-5 did cause an increase in the level of p53 as H661 cells contain mutant p53 (Liu et al., 2004). These results indicate that the expression levels of mutant p53 and Bcl2 family members modulate SCEPP-5-induced cell apoptosis. SCEPP-5 also caused the release of cytochrome $c$ from mitochondria.

\subsection{Regulation of XIAP, activation of caspase-3 and cleavage of PARP in SCEPP-5 induced H661 cell apoptosis}

To determine whether the activity of caspase- 3 is associated with the expression of XIAP protein in the SCEPP-5 induced cell apoptosis, we evaluated the various proteins expression in $\mathrm{H661}$ cells after exposure to $0.1 \%$ DMSO (control) and $50 \mu \mathrm{g} / \mathrm{ml} \mathrm{SCEPP-}$ 5 for $0,6,12$ and $24 \mathrm{~h}$. As shown in Fig. 4B, the activation of caspase- 3 after $12 \mathrm{~h}$ and $24 \mathrm{~h}$ of $50 \mu \mathrm{g} / \mathrm{ml}$ SCEPP-5 incubation was corroborated by the appearance of a $20 \mathrm{kDa}$ fragment of caspase3 , which was resulted from the proteolytic processing of pro-caspase-3 (32 kDa). The expression of XIAP protein was gradually disappeared in a dose- and time-dependent manner (Fig. 4A and B). PARP proform (molecular mass, $116 \mathrm{kDa}$ ) was cleaved to give a $85 \mathrm{kDa}$ fragment in SCEPP- 5 treated cells at 12 and $24 \mathrm{~h}$ after treatment. Among the various substrates that are broken down during apoptosis, PARP is recognized as a useful indicator of apoptosis (Wolf and Green, 1999).

\section{Discussion}

The present study demonstrated that variation in methods of preparation and extraction procedures could result in a different pattern of active compounds and different magnitude of pharmacological activities. Consistent with other studies, SFE affords an advantage over more conventional extraction techniques (Palma and Taylor, 1999), as its extracts exhibited a higher antioxidant 
A

\begin{tabular}{lcccc}
\multicolumn{7}{c}{ SCEPP-5 } \\
\hline 0 & 1 & 10 & 30 & $50 \mu \mathrm{g} / \mathrm{ml}$
\end{tabular}

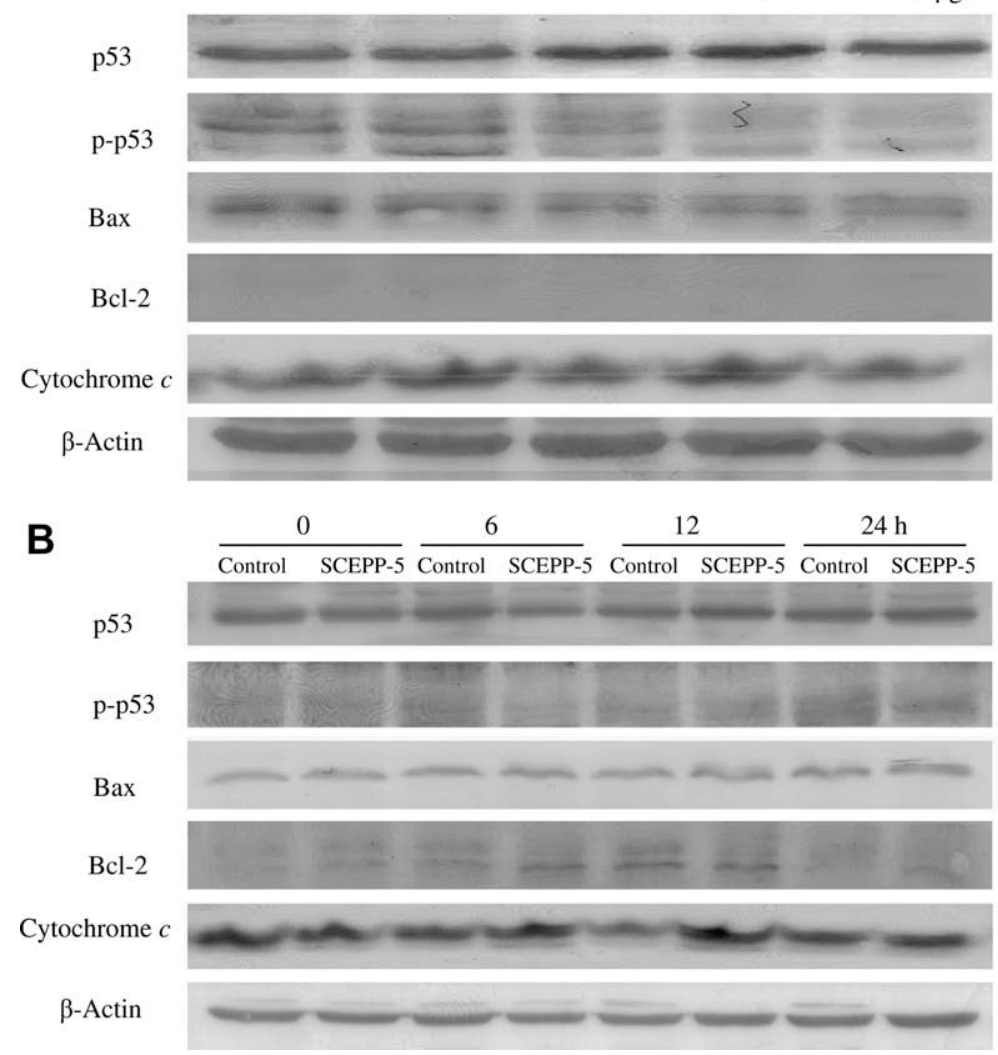

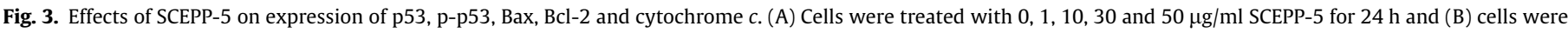
treated with $0.1 \%$ DMSO (control) and $50 \mu \mathrm{g} / \mathrm{ml} \mathrm{SCEPP-5}$ for $0,6,12$ and $24 \mathrm{~h}$. $\beta$-Actin was used as a positive control.

power than extracts obtained by other classical methods (Tipsrisukond et al., 1998). In this study, the optimal condition for SFE$\mathrm{CO}_{2}$ extraction of PP material was at 400 bar pressure at $60{ }^{\circ} \mathrm{C}$ and with $5 \%$ ethanol as a mixing modifier, under which the yield of extract can be substantially increased.

Flavonoids and phenolic compounds have been shown to possess antioxidant and anti-inflammatory properties (Middleton et al., 2000). Studies have indicated that the use of organic solvent with $\mathrm{SFE}-\mathrm{CO}_{2}$ extraction can increase the efficiency in isolating phenolic compounds from grape seeds (Palma and Taylor, 1999; Ashraf-Khorassani and Taylor, 2004), and flavonoids from Scutellaria lateriflora (Bergeron et al., 2005). Our results showed that total flavonoids and phenolic compounds were enriched in the SCEPP5 , which was extracted by SFE- $\mathrm{CO}_{2}$ with $5 \%$ ethanol as modifier.

Green tea polyphenol such as epigallocatechin-3-gallate and epigallocatechin displayed strong growth inhibitory effects against lung cancer cell lines H661 and H1299 (Yang et al., 1998). The SFE$\mathrm{CO}_{2}$ extract of Cordyceps sinensis was reported to have antihepatoma and antioxidative effects (Wang et al., 2005). In this study, we showed that the SFE- $\mathrm{CO}_{2}$ extract, SCEPP-5, was able to inhibit cell proliferation and induce cell apoptosis. This was confirmed by two independent methods, namely the MTT analysis and the DNA fragmentation method. A simultaneous analysis of cell cycle distribution (sub-G1 peak) in SCEPP-5 treated H661 cultures also revealed does-dependent increase in the percentage of apoptotic cells. A pronounced effect was noted at $50 \mu \mathrm{g} / \mathrm{ml}$ SCEPP-5 and the cell cycle progression was found to arrest in the $S$ phase.

The ethanolic extract of $P$. peruviana has been reported to induce Hep G2 cell apoptosis through the release of mitochondria cytochrome $c$ into the cytoplasm and activation of caspase-3 $(\mathrm{Wu}$ et al., 2004a). Treatment of H661 cells with SCEPP-5 exhibited the up-regulation of $\mathrm{p} 53$ and Bax proteins, releasing of cytochrome $c$, and the down-regulation of $\mathrm{Bcl}-2$, as well as causing the PARP to cleave upon the activation of caspase-3.

Several studies have shown that the Bcl-2 family of proteins is the central of apoptotic regulation (Yu et al., 2003; Choi et al., 2004). Overexpression of $\mathrm{Bcl}-2$ and $\mathrm{Bcl}-\mathrm{xL}$ aborts the apoptotic response while Bax, Bid and Bak activity promotes cell death (Cory and Adams, 2002). Our results displayed that SCEPP-5 activated mutant p53, and caused an up-expression of Bax as well as triggering down-expression of Bcl-2, and consequently promoting apoptotic activity in H661 cells. p53 has been reported to mediate Bax up-regulation (Karpinich et al., 2002). The activation of p53 could lead to p53 dependent and resulted in the release of cytochrome $c$, activation of caspase- 3 and cleavage of PARP.

IAPs such as XIAP, c-IAP-1, cIAP-2 were shown to inhibit apoptosis due to their function as direct inhibitors of activated caspases $(-3,-7$ and -9$)$, regulating cell cycle progression and modulating receptor-mediated signal transduction (Roy et al., 1997). Suppression of XIAP protein levels was found to increase with the time of SCEPP-5 treatment. The down-regulation of XIAP and Bcl-2 proteins promoted the activation of caspase- 3 and resulted in $\mathrm{H} 661$ cell apoptosis, whereas over expression of XIAP results in the blocking of pro-apoptotic signaling and the execution of caspases, and thus inhibiting tumor cell death. Therefore, increase expression of XIAP might protect cells from premature apoptosis and desquamation (Bilim et al., 2003).

In summary, our studies demonstrated that the $\mathrm{SFE}-\mathrm{CO}_{2}$ extract "SCEPP-5" possessed the highest polyphenol content and exhibited the most potent antiproliferative effect in $\mathrm{H} 661$ cells. Its treatment 


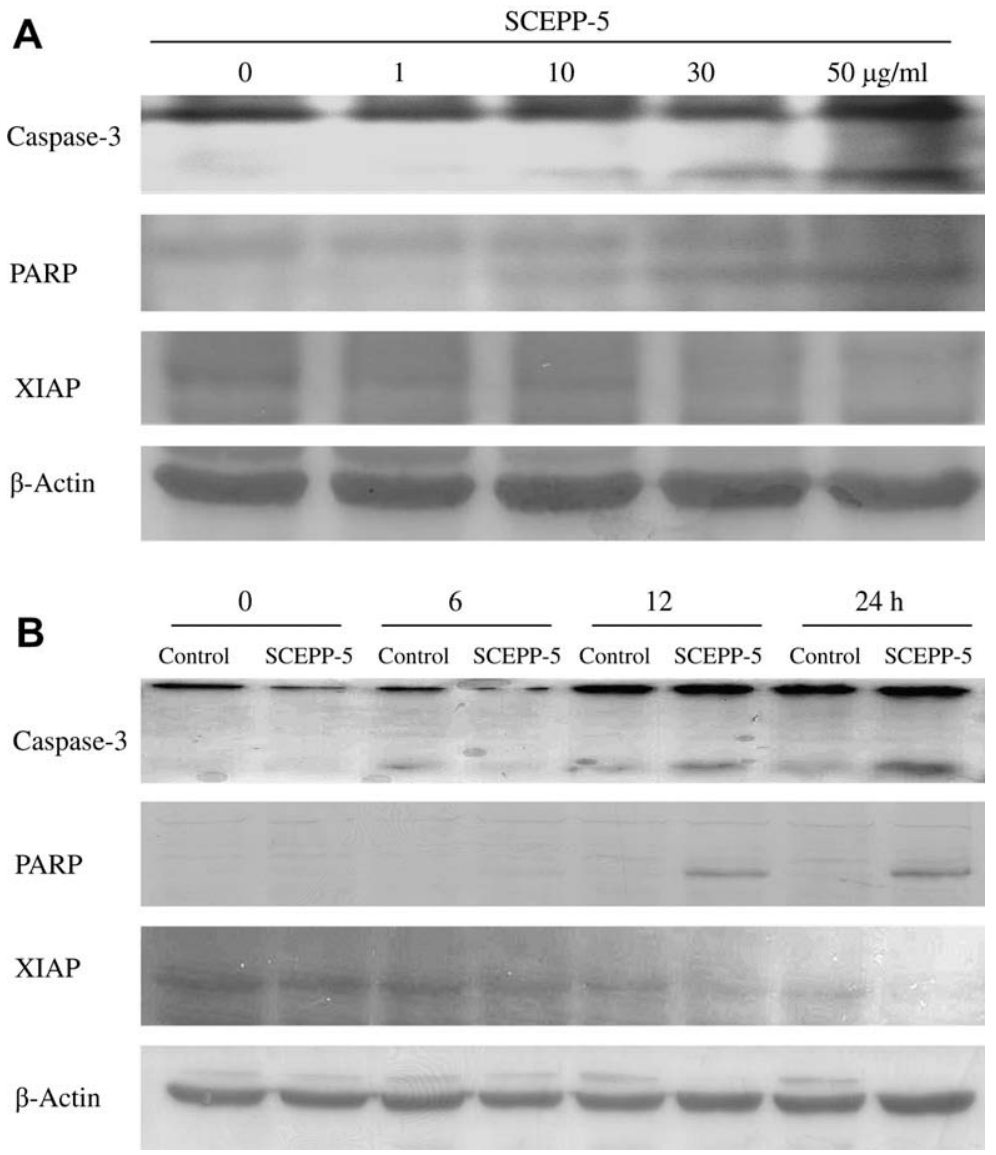

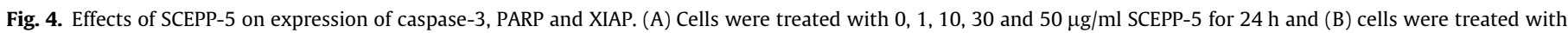
$0.1 \%$ DMSO (control) and $50 \mu \mathrm{g} / \mathrm{ml}$ SCEPP-5 for $0,6,12$ and $24 \mathrm{~h}$. $\beta$-Actin was used as a positive control.

caused cell cycle arrest at $\mathrm{S}$ phase, increased expression of the DNA fragmentation, and the accumulation of p53, as well as inducing cytochrome $c$ release, which further activated pro-caspase- 3 and consequently caused $\mathrm{H} 661$ cell death. In addition, the inhibitory effect of SCEPP-5 on H661 cell proliferation was also found to be through the up-regulation of pro-apoptotic proteins (Bax), and the down-regulation of anti-apoptotic protein (Bcl-2) and inhibitor of apoptosis protein (IAP). These results suggest that the apoptotic induction of SCEPP-5 in human H661 cells could be mediated through the p53 signaling transduction pathway and modification of Bax and XIAP proteins. Furthermore, the results have also provided additional scientific evidences to confirm the traditional claims of $P$. peruviana and important pharmacological backgrounds for the potential use of its supercritical fluid extract as products for the prevention of cancer.

\section{Conflict of interest statement}

The authors declared that there is no conflict of interest.

\section{References}

Adams, J.M., Cory, S., 1998. The Bcl-2 protein family: arbiters of cell survival. Science $281,1322-1326$

Ashraf-Khorassani, M., Taylor, L.T., 2004. Sequential fractionation of grape seeds into oils, polyphenols, and procyanidins via a single system employing $\mathrm{CO}_{2}-$ based fluids. J. Agric. Food Chem. 52, 2440-2444.

Bergeron, C., Gafner, S., Clausen, E., Carrier, D.J., 2005. Comparison of the chemical composition of extracts from Scutellaria lateriflora using accelerated solven extraction and versus standard hot water or $70 \%$ ethanol extraction. J. Agric. Food Chem. 53, 3076-3080.
Bilim, V., Kasahara, T., Hara, N., Takahashi, K., Tomita, Y., 2003. Role of XIAP in the malignant phenotype of transitional cell cancer (TCC) and therapeutic activity of XIAP antisense oligonucleotides against multidrug-resistant TCC in vitro. Int. J. Cancer 103, 29-37.

Borner, C., 2003. The Bcl-2 protein family: sensors and checkpoints for life-or-death decisions. Mol. Immunol. 39, 615-647.

Cain, K., Bratton, S.B., Cohen, G.M., 2002. The Apaf-1 apoptosome: a large caspaseactivating complex. Biochimie 84, 203-214.

Chiang, H.C., Jaw, S.M., Chen, C.F., Kan, W.S., 1992a. Antitumor agent, physalin F from Physalis angulata L.. Anticancer Res. 12, 837-843.

Chiang, H.C., Jaw, S.M., Chen, P.M., 1992b. Inhibitory effects of physalin B and physalin F on various human leukemia cells in vitro. Anticancer Res. 12, 11551162.

Choi, S.E., Sohn, S., Cho, J.W., Shin, E.A., Song, P.S., Kang, Y., 2004. 9Hydroxypheophorbide $\alpha$-induced apoptotic death of MCF-7 breast cancer cells is mediated by c-Jun N-terminal kinase activation. J. Photochem. Photobiol. B: Biol. 73, 101-107.

Cory, S., Adams, J.M., 2002. The Bcl2 family: regulators of the cellular life-or-death switch. Nat. Rev. Cancer 2, 647-656.

Ismail, N., Alam, M., 2001. A novel cytotoxic flavonoid glycoside from Physalis angulata. Fitoterapia 72, 676-679.

Karpinich, N.O., Tafani, M., Rothman, R.J., Russo, M.A., Farber, J.L., 2002. The course of etoposide-induced apoptosis from damage to DNA and p53 activation to mitochondrial release of cytochrome $c$. J. Biol. Chem. 277, 16547-16552.

Kroemer, G., Reed, J.C., 2000. Mitochondrial control of cell death. Nat. Med. 6, 513519.

Lee, Y.J., Kuo, H.C., Chu, C.Y., Wang, C.J., Lin, W.C., Tseng, T.H., 2003. Involvement of tumor suppressor protein p53 and p38 MAPK in caffeic acid phenethyl esterinduced apoptosis of C6 glioma cells. Biochem. Pharmacol. 66, 2281-2289.

Leal, P.F., Braga, M.E.M., Sato, D.N., Carvalho, J.E., Marques, M.O.M., Meireles, M.A.A., 2003. Functional properties of spice extracts obtained via supercritical fluid extraction. J. Agric. Food Chem. 51, 2520-2525.

Liu, L.F., Liang, C.H., Shiu, L.Y., Lin, C.C., Kuo, K.W., 2004. Action of solamargine on human lung cancer cells-enhancement of the susceptibility of cancer cells to TNFs. FEBS Lett. 577, 67-74.

McNeish, I.A., McKay, S.B.T., Tenev, T., Marani, M., Lemoine, N.R., 2003. Expression of Smac/Diablo in ovarian carcinoma cells induces apoptosis via a caspase-9mediated pathway. Exp. Cell Res. 286, 186-198.

Meier, P., Finch, A., Evan, G., 2000. Apoptosis in development. Nature 407, 796-801. 
1138

S.-J. Wu et al./Food and Chemical Toxicology 47 (2009) 1132-1138

Middleton Jr., E., Kandaswami, C., Theoharides, T.C., 2000. The effects of plant flavonoids on mammalian cells: implications for inflammation, heart disease and cancer. Pharmacol. Rev. 52, 673-751.

Muller, M., Wilder, S., Bannasch, D., Israeli, D., Lehlbach, K., Li-Weber, M., Friedman, S.L., Galle, P.R., Stremmel, W., Oren, M., Kramer, P.H., 1998. P53 activates the CD95 (APO-1/Fas) gene in response to DNA damage by anticancer drugs. J. Exp. Med. 188, 2033-2045.

Palma, M., Taylor, L.T., 1999. Extraction of polyphenolic compounds from grape seeds with near critical carbon dioxide. J. Chromatogr. A 849, 117-124.

Perry, L.M., 1980. Medicinal Plants of East and Southeast Asia - Attributed Properties. The MIT Press, Massachusetts. p. 393.

Roy, N., Deveraux, Q.L., Takahashi, R., Salvesen, G.S., Reed, J.C., 1997. The c-IAP-1 and c-IAP-2 proteins are direct inhibitors of specific caspases. EMBO J. 16, 69146925.

Thompson, C.B., 1995. Apoptosis in the pathogenesis and treatment of disease. Science 267, 1456-1462.

Tipsrisukond, N., Fernando, L.N., Clarke, A.D., 1998. Antioxidant effects of essential oleoresin of black pepper from supercritical carbon dioxide extractions in ground pork. J. Agric. Food Chem. 46, 4329-4333.

Wolf, B.B., Green, D.R., 1999. Suicidal tendencies: apoptotic cell death by caspase family proteinases. J. Biol. Chem. 274, 20049-20052.

Wang, B.J., Won, S.J., Yo, Z.R., Su, C.L., 2005. Free radical scavenging apoptotic effects of Cordyceps sinensis fractionated by supercritical carbon dioxide. Food Chem. Toxicol. 43, 543-552.

Woo, J.H., Kim, Y.H., Choi, Y.J., Kim, D.G., Lee, K.S., Be, J.H., Min do, S., Chang, J.S., Jeong, Y.J., Lee, Y.H., Park, J.W., Kwon, T.K., 2003. Molecular mechanisms of curcumin-induced cytotoxicity: induction of apoptosis through generation of reactive inhibition of Att. Carcinogenesis 24, 1199-1208.

Wu, S.J., Kg, L.T., Chen, C.H., Lin, D.L., Wang, S.S., Lin, C.C., 2004a. Antihepatoma activity of Physalis angulate and P. peruvians extracts and their effects on apoptosis in human Hep G2 cells. Life Sci. 74, 2061-2073.

Wu, S.J., Kg, L.T., Huang, Y.M., Lin, D.L., Wang, S.S., Huang, S.N., Lin, C.C., 2005. Antioxidant of Physalis peruviana. Biol. Pharm. Bull. 28, 963-966.

Wu, S.J., Kg, L.T., Lin, D.L., Wang, S.S., Lin, C.C., 2004b. Physalis peruvian extract induces apoptosis in human Hep G2 cells through CD95/CD95L system and the mitochondrial signaling transduction pathway. Cancer Lett. 215, 199-208.

Wu, S.J., Tai, J.Y., Chang, S.P., Lin, D.L., Wang, S.S., Huang, S.N., Kg, L.T., 2006 Supercritical carbon dioxide extract exhibits enhanced antioxidant and antiinflammatory activities of Physalis peruviana. J. Ethnopharmacol. 108, 407-413.

Yang, G.Y., Liao, J., Kim, K., Yurkow, E.J., Yang, C.S., 1998. Inhibition of growth and induction of apoptosis in human cancer cell lines by tea polyphenols. Carcinogenesis 19, 611-616.

Yang, C., Xu, Y.R., Yao, W.X., 2002. Extraction of pharmaceutical components from Ginkgo biloba leaves using supercritical carbon dioxide. J. Agric. Food Chem. 50, 846-849.

Yamaguchi, H., Bala, K., Wang, H.G., 2003. Bax plays a pivotal role in thapsigargininduced apoptosis of human colon cancer HCT116 cells by controlling Smac/ Diablo and Omi/HtrA2 release from mitochondria. Cancer Res. 63, 1483-1489.

Yu, W., Sanders, B.G., Kline, K., 2003. RRR- $\alpha$-tocopheryl succinate-induced apoptosis of human breast cancer cells involves Bax translocation to mitochondria. Cancer Res. 63, 2483-2491. 